Atmos. Chem. Phys. Discuss., https://doi.org/10.5194/acp-2019-251

Manuscript under review for journal Atmos. Chem. Phys.

Discussion started: 17 April 2019

(c) Author(s) 2019. CC BY 4.0 License.

\title{
Global modeling of fungal spores with the EMAC chemistry- climate model: uncertainties in emission parametrizations and observations
}

Meryem Tanarhte ${ }^{1,2}$, Sara Bacer ${ }^{1}$, Susannah M. Burrows ${ }^{3}$, J. Alex Huffman ${ }^{4}$, Kyle M. Pierce ${ }^{4}$, Andrea Pozzer ${ }^{1}$, 5 Roland Sarda-Estève ${ }^{5}$, Nicole J. Savage ${ }^{4^{*}}$, Jos Lelieveld ${ }^{1,6}$

${ }^{I}$ Max Planck Institute for Chemistry, Department of Air Chemistry, Mainz, Germany

${ }^{2}$ University Hassan II-Casablanca, Faculté des Sciences et Techniques, Mohammedia, Morocco

${ }^{3}$ Atmospheric Science and Global Change Division, Pacific Northwest National Laboratory, Richland, WA, USA

${ }^{4}$ University of Denver, Department of Chemistry and Biochemistry,, Denver, USA

${ }^{5}$ Laboratoire des Sciences du Climat et de l'Environnement, CEA/CNRS-UVSQ, 91191, Gif/Yvette, France

${ }^{6}$ The Cyprus Institute, Nicosia, Cyprus

*Now at Aerosol Devices, Inc.

Correspondence to: Meryem Tanarhte (meryem.tanarhte@mpic.de)

Abstract. Primary biological aerosol particles (PBAPs) may impact human health and aerosol-cloud-climate interactions. The role of PBAPs in the earth system is associated with large uncertainties, for example of source estimates and the atmospheric lifetime. We used a chemistry-climate model to simulate PBAPs in the atmosphere including bacteria and fungal spores. Three fungal spore emission parameterizations have been evaluated against an updated set of spore counts synthesized from observations reported in the literature. The comparison indicates an optimal fit for the emission parameterization proposed by Heald and Spracklen (2009) and adapted by Hoose et al. (2010) for particle sizes of $5 \mu \mathrm{m}$ or $3 \mu \mathrm{m}$, although the model still overpredicts PBAP concentrations in some locations. The correlations between the spore count observations and meteorological parameters simulated by the model show a strong dependence on the leaf area index in non-urban areas and the specific humidity in urban areas. Additional evaluation was performed by comparing our combined bacteria and fungal spore simulations to a global dataset of fluorescent biological aerosol particle (FBAP) concentrations. The model predicts the total sum of measured PBAP concentrations relatively well, typically within a factor of two of FBAP. Further, the modeled fungal spore results deviate from the FBAP concentrations when used as a rough proxy for spores, depending on the particle size used in the parametrization. Uncertainties related to technical aspects of the FBAP and direct- 
Atmos. Chem. Phys. Discuss., https://doi.org/10.5194/acp-2019-251

Manuscript under review for journal Atmos. Chem. Phys.

Discussion started: 17 April 2019

(c) Author(s) 2019. CC BY 4.0 License.

counting spore measurements challenge the ability to further refine quantitative comparison on this scale. Additional long-term data of better quality are needed to improve emission parameterizations.

\section{Introduction}

Primary biological aerosol particles (PBAPs) are diverse and include bacteria, fungal spores, viruses, pollen as well

5 as fragments of these and other organisms. The growing interest in PBAP is related to the effects they may have on agricultural crops, human health and atmospheric chemistry (Deguillaume et al., 2008). Airborne bioparticles may influence climate by acting as ice nuclei (IN) especially in mixed phase clouds. The abundance of atmospheric IN can influence cloud development, impacting cloud radiative properties and the location and timing of rain formation (Bangert et al., 2012; DeMott et al., 2010; French et al., 2018; Prenni et al., 2007).

10

Fungal spores are the most abundant and the most genetically diverse PBAPs in the atmosphere (Lacey, 1981). They are also of critical importance because many species can induce considerable economic losses, acting as plant pathogens or triggering respiratory diseases and allergenic processes in humans (Reinmuth-Selzle et al., 2017). Inhalation of spores in sufficient quantities causes various respiratory diseases including various infectious diseases, allergic rhinitis, asthma, and other allergic reactions (Burge and Rogers, 2000; Bush and Portnoy, 2001). More than 100 species of fungal spores have been shown to contribute to respiratory disorders (Green et al., 2005). Fungal spores have been identified and characterized using a large range of methods, including traditional methods such as microscopic analysis and cultivation methods, and modern methods using molecular techniques (Caruana, 2011; Després et al., 2012; Griffiths and Decosemo, 1994). Many studies have been used to estimate the concentration of fungal spores in the atmosphere. However, a standardised procedure to quantify spore concentrations is still lacking, which leads to very heterogeneous results and hinders direct comparisons of observations across different studies.

Estimates of the total global emissions of fungal spores emitted into the atmosphere diverge greatly across the literature, varying from $8 \mathrm{Tg} \mathrm{yr}^{-1}$ (Sesartic and Dallafior, 2011) to $186 \mathrm{Tg} \mathrm{yr}^{-1}$ (Jacobson and Streets, 2009). Fungal

25 spores contribute up to $\sim 45 \%$ of the coarse particulate matter over the tropical rainforest (Després et al., 2012) and their number and mass concentrations are typically about $10^{3}-10^{4} \mathrm{~m}^{-3}$ and $\sim 1 \mu \mathrm{g} \mathrm{m}^{-3}$, respectively (FröhlichNowoisky et al., 2016). The number and composition of airborne fungal spores depend on complex interactions between biological and environmental factors, including the climate and local ecological systems (Grinn-Gofron and Bosiacka, 2015). Meteorological factors influence their production, release, and transport, which is contingent on geographical areas, and vary seasonally. Interactions with PBAPs can also depend on the emitting species involved (Elbert et al., 2007; Fröhlich-Nowoisky et al., 2009; Hirst, 1953; Levetin and Dorsey, 2006; Li and Kendrick, 1995; Oliveira et al., 2009). 
Atmos. Chem. Phys. Discuss., https://doi.org/10.5194/acp-2019-251

Manuscript under review for journal Atmos. Chem. Phys.

Discussion started: 17 April 2019

(c) Author(s) 2019. CC BY 4.0 License.

Global and regional models have been used to evaluate fungal spore emissions, transport and their impact on the hydrological cycle by acting as cloud condensation nuclei (CCN) and IN (Heald and Spracklen, 2009; Hoose et al., 2010; Hummel, 2018; Hummel et al., 2015; Sesartic and Dallafior, 2011; Sesartic et al., 2013; Spracklen and

5 Heald, 2014). These models require the representation of the emissions and particle properties influencing transport and removal from the atmosphere through suitable parameterizations. Large uncertainties in the number concentrations remain, especially due to inherent uncertainties in the emission estimates of PBAPs. Past evaluations of these emission parameterizations have only used a few point measurements and have never been extended to a global long-term set of observations obtained using different measurement techniques.

10 The goal of this study is to evaluate three fungal spore emission parameterizations available in the literature and compare their number concentrations, simulated with a global model, to an updated new set of observations. We use a chemistry-climate model to simulate the PBAPs present in the atmosphere including bacteria and fungal spores. We compare our simulated fungal spore concentrations to a global dataset of spore counts synthesized from the literature and the sum of modeled fungal spore and bacteria concentrations to another global dataset of

15 fluorescent biological aerosol particle (FBAP). These measurements have been performed with real-time techniques that detect the fluorescence signal through UV excitation of fluorophores commonly present biological materials (e.g., fungal spores, bacteria, and leaf fragments). To our knowledge, this is the first evaluation of fungal spore emission parametrizations against a global collection of these newly-available observations. It constitutes an important step towards understanding the many still-remaining uncertainties and questions related to the PBAP representation in global atmospheric models.

\section{Materials and methods}

\subsection{Model description}

The global ECHAM5/MESSy Atmospheric Chemistry - Climate (EMAC) model (ECHAM version 5.3.01, MESSy version 2.5.2 (Jöckel et al., 2005; Jöckel et al., 2016) was used to simulate the emissions and transport of biological particles. PBAPs have been included in the form of fungal spores and bacteria-containing particles by using the emission parameterizations described below. Removal processes of particles simulated by the model include sedimentation, dry deposition, impaction scavenging, and nucleation scavenging by liquid, mixed-phase, and ice clouds. PBAP dry and wet depositions are treated as described for other aerosol species (see (Burrows et al., 2009; Pozzer et al., 2012; Pringle et al., 2010) and references therein). All PBAP classes are treated as having a lognormal distribution with modal-scale parameter $\sigma=1$ and density of $1 \mathrm{~g} \mathrm{~cm}^{-3}$. We assumed that all particles can become activated as cloud condensation nuclei when calculating particle removal processes by wet deposition, 
Atmos. Chem. Phys. Discuss., https://doi.org/10.5194/acp-2019-251

Manuscript under review for journal Atmos. Chem. Phys.

Discussion started: 17 April 2019

(c) Author(s) 2019. CC BY 4.0 License.

(c) (1)

Atmospheric

Chemistry

and Physics

Discussions

as described in (Burrows et al., 2009). Fungal spores and bacteria-containing particles of different size are transported as passive tracers, i.e., their concentrations are influenced by model processes such as dry deposition and scavenging by clouds and rain, but do not interact with radiation or change cloud microphysical properties. The sedimentation and dry deposition of the particles are treated as described in (Kerkweg et al., 2006). Wet deposition

5 of the particles is described in (Tost et al., 2006). We use the global Leaf Area Index (LAI) distribution by (Deng et al., 2006) to calculate the fungal spores emission fluxes.

For the present study, we applied EMAC in the T63L31 resolution; with a spherical truncation of T63 (corresponding to a grid of approximately $1.9^{\circ} \times 1.9^{\circ}$ in latitude and longitude, or approximately $140 \times 210 \mathrm{~km}$ at 10 middle latitudes) and 31 vertical hybrid pressure levels up to $10 \mathrm{hPa}$. The model was run for five consecutive years without meteorological nudging, from the year 2000 until 2004. Monthly sea surface temperatures and sea ice concentrations from AMIP-II climatologies were used to provide boundary conditions for the atmospheric circulation. Climatological averages for PBAP distribution for the last four years of the simulation were used after a 1-year spin-up period. The EMAC model, evaluated in (Jöckel et al., 2005; Jöckel et al., 2016) and used in

15 similar configurations, has been shown to be capable of realistic simulations of aerosol transport and deposition for the transport of African dust to Europe (Glaser et al., 2012) and radioactive aerosol particles from the Chernobyl and Fukushima accidents (Christoudias and Lelieveld, 2013; Lelieveld et al., 2012). We emphasize that the simulation results represent a climatology rather than specific weather conditions under which some PBAB samples may have been collected, hence we expect mean concentrations and distributions to be represented by the model rather than distinct measurement data.

\subsection{PBAP emissions}

\subsubsection{Fungal spores}

25

We compare three fungal spore emission parameterizations previously used in global and regional modeling studies. Firstly, fungal spore emission fluxes have been derived by Heald and Spracklen (2009) for fine and coarse modes from an empirically optimized scheme where emissions are linear functions of LAI (in $\mathrm{m}^{2} \mathrm{~m}^{-2}$ ) and the specific humidity q (in $\mathrm{kg} \mathrm{kg}^{-1}$ ) at the surface. In order to match their emission estimates, Hoose et al. (2010) applied the following formulation to calculate the emission flux, assuming a mean spore diameter of $5 \mu \mathrm{m}$ (HO5 hereafter):

$$
F_{H O 5}=500 \mathrm{~m}^{-2} \mathrm{~s}^{-1} \times \frac{L A I}{5} \times \frac{q}{1.5 \times 10^{-2} \mathrm{kgkg}^{-1}}
$$


Atmos. Chem. Phys. Discuss., https://doi.org/10.5194/acp-2019-251

Manuscript under review for journal Atmos. Chem. Phys.

Discussion started: 17 April 2019

(c) Author(s) 2019. CC BY 4.0 License.

(c) (i)

Another formulation of this parameterization has been rescaled in this work in order to match the emission estimates calculated by Heald and Spracklen (2009) assuming a spore diameter of $3 \mu \mathrm{m}$ (HO3 hereafter):

$$
F_{H O 3}=2315 m^{-2} s^{-1} \times \frac{L A I}{5} \times \frac{q}{1.5 \times 10^{-2} k g k g^{-1}}
$$

The second parameterization we tested uses the emission number fluxes of fungal spores calculated by $\underline{\text { Sesartic and }}$ 5 Dallafior (2011) (SD hereafter) for the five different ecosystems defined by Olson et al. (2001). We used the bestestimate number fluxes weighted by the area fraction of the respective MODIS ecosystems in the gridbox $\mathrm{E}_{\mathrm{i}}$. We lumped the categories defined in the MODIS classifications to match similar sets of lumped ecosystems used by Sesartic and Dallafior (2011) (i.e., derived from the Olson ecosystem types). The total emission flux for fungal spores is calculated assuming a mean diameter of $3 \mu \mathrm{m}$ given as:

10

$$
\begin{aligned}
F_{S D}=194 m^{-2} s^{-1} \times E_{\text {tropicalforest }}+214 m^{-2} s^{-1} \times E_{\text {forest }}+1203 m^{-2} s^{-1} \times E_{\text {shrub }}+165 m^{-2} s^{-1} \times E_{\text {grassland }} \\
+ \\
+2509 \times m^{-2} s^{-1} \times E_{\text {crop }}
\end{aligned}
$$

The third parameterization, derived by Hummel et al. (2015) (HU hereafter), is adapted to measurements of airborne fluorescent biological particles across northern Europe. Similar to the parameterization of Heald and Spracklen (2009), this recent parameterization depends on LAI and specific humidity, and is extended to include the surface temperature $\mathrm{T}(\mathrm{K})$ :

$$
F_{H U}=b_{1} \times(T-275.82)+b_{2} \times q \times L A I
$$

where $b_{1}=20.426$ and $b_{2}=3.9310^{4}$.

For each parameterization, the mean diameter was assigned according to the recommendations made in the three studies: $5 \mu \mathrm{m}$ for $\mathrm{HO} 5,3 \mu \mathrm{m}$ for $\mathrm{HU}$, and $3 \mu \mathrm{m}$ for $\mathrm{SD}$, and we used $3 \mu \mathrm{m}$ for $\mathrm{HO} 3$.

\subsubsection{Bacteria}

While the focus of this study is on the simulation of fungal spore concentrations, bacteria-containing particles are expected to contribute significantly to FBAP concentrations. In order to examine their possible contribution to FBAPs (discussed in more detail in the section 3.4), we also simulated bacteria-containing particles (see Supplementary Information), using an emission parameterization previously developed for EMAC on the basis of observed atmospheric concentrations of bacteria-containing particles in different ecosystems (Burrows et al., 2009a; Burrows et al., 2009b). The uncertainties in this parameterization and the underlying observations have 
Atmos. Chem. Phys. Discuss., https://doi.org/10.5194/acp-2019-251

Manuscript under review for journal Atmos. Chem. Phys.

Discussion started: 17 April 2019

(c) Author(s) 2019. CC BY 4.0 License.

(c) (1)

Atmospheric

Chemistry

and Physics

Discussions

been discussed in detail in (Burrows et al., 2009a; Burrows et al., 2013). Further evaluation of the simulated bacteria-containing particle concentrations is beyond the scope of this study; here we include these concentrations to enable a qualitative comparison with observed FBAP concentrations.

\subsection{Data description}

\section{2.3.1. Spores counts}

We compare the fungal spore concentrations calculated by EMAC using the three emission parameterizations described above, to observations collected through literature review (see their geographical locations in Figure 1).

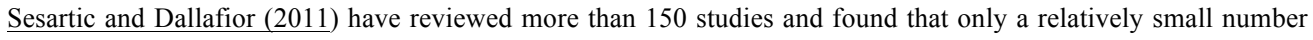

10 (35) reported total fungal spore concentration measurements, excluding observations that employed cultivation of a subset of species (e.g., in a petri dish) and measurements that report only mass concentrations instead of spore counts. We updated this dataset with observations that meet the same criteria, mostly from studies published since 2011. Our updated review revealed that much of the relevant literature reports only concentrations of the genetic diversity of fungal taxa and not their total concentrations, hence explaining the scarcity of data that can be used for model evaluations. The uncertainties related to these methods and discussed in detail in Sesartic and Dallafior (2011) include heterogeneous measurement methods, which differ in the devices and methods used for spore trapping, choice of impaction media, choice of airflow, period of measurements, placement of the sampling device, choice of the impaction media, choice of nutrient medium and incubation duration and temperature (for viable counts), and counting method. The observations used for comparison with model results are listed in Table SI2.

Modeled concentrations have been sampled to match the period of observation for each location. Since we do not compute actual meteorology but rather climatological conditions, our model results do not represent instantaneous local processes, especially when they vary strongly on a small scale. However, we expect that time averaging limits such biases. We differentiate the data by ecosystem using the MODIS categories and the description provided by the reference. Most of the observations that met our criteria for inclusion have been taken in urban areas.

25

\subsubsection{FBAP observations}

Over the last two decades real-time measurement techniques have provided opportunities to monitor airborne PBAP continuously at relatively high time-resolution. Techniques involving laser/light-induced fluorescence (LIF) have been particularly effective in rapidly providing information about PBAP in real time e.g. (Fennelly et al., 2018; Huffman and Santarpia, 2017; Kaye et al., 2005; Pan et al., 2009; Saari et al., 2014; Sivaprakasam et al., 2009). Among many available instruments, two commercially available LIF biosensors have been widely applied 
Atmos. Chem. Phys. Discuss., https://doi.org/10.5194/acp-2019-251

Manuscript under review for journal Atmos. Chem. Phys.

Discussion started: 17 April 2019

(c) Author(s) 2019. CC BY 4.0 License.

Atmospheric

Chemistry

and Physics

Discussions

to ambient bioparticle monitoring and have helped to reveal fine detail about atmospheric PBAP patterns not previously observed e.g. (Gabey et al., 2010; Huffman et al., 2013; Huffman et al., 2010; Perring et al., 2015; Schumacher et al., 2013). For example, the ultraviolet aerodynamic particle sizer (UV-APS; TSI, Inc.) and the wideband integrated bioaerosol sensor (WIBS; University of Hertfordshire or Droplet Measurement Technologies)

5 both characterize biological particles in real-time based on the intensity of fluorescence emission observed from individual particles after pulsed excitation at wavelengths characteristic for common biofluorophores (Foot et al., 2008; Hairston et al., 1997; Pöhlker et al., 2012). Despite the uncertainties related to this type of measurement (Huffman et al., 2012; Pöhlker et al., 2012; Savage et al., 2017), the FBAPs detected by the UV-APS or WIBS have been successfully used in some cases as a lower-limit for the atmospheric abundance of PBAPs in the supermicron (>1 $\mu \mathrm{m}$ ) size range (Huffman et al., 2010).

In this context, however, it is important to mention a few caveats implicit with the assumption linking FBAPs to PBAPs. First, real-time LIF instruments can only detect the physical properties of particles (i.e., fluorescence and size) and cannot directly determine whether a particle is of biological origin. By applying certain analytical strategies, however, a given ensemble of particles may be assigned as PBAP with varying degrees of certainty. In some cases weakly fluorescing biological particles can escape the LIF detection e.g. (Huffman et al., 2012) and in other cases highly fluorescent particles of non-biological origin such as certain kinds of aged brown secondary organic aerosols, diesel soot particles, and some humic-like substances (HULIS) can interfere with the LIF detection leading to an overestimation of PBAPs e.g. (Gabey et al., 2013; Huffman et al., 2010; Savage et al., 2017). Bioparticle size also plays an important role in LIF detection. For example, viruses are generally too small to be detected by LIF instruments, and almost all species of pollen are too large to be detected without fragmentation or instrument modification (O'Connor et al., 2011). Additionally, technical differences in instrument design, the choice of detection channels, and operational parameters can have significant effects on the reported number concentration of FBAPs and the quality of their correlation with PBAP classes (Savage et al., 2017). Nevertheless, we use the FBAP numbers reported by UV-APS and WIBS instruments as a rough proxy for PBAP, comparing the observed FBAP numbers both with more direct PBAP measurements and with model outputs.

FBAP observations using UV-APS and the FL3 channel from the WIBS-3 and WIBS-4A instruments are listed in

Table 3. The majority of FBAP data were extracted from published reports without additional analysis or as tabulated by previous reviews (Fennelly et al., 2018; Saari et al., 2015; Yu et al., 2016), and all original data sources are specified in Table 3. By limiting WIBS data to only the FL3 channel, the number concentrations are expected to be significantly lower than total FBAP numbers often reported, but are used here for a better correlation with the UV-APS, due to similarities in fluorescence excitation and emission bands (Foot et al., 2008; 
Atmos. Chem. Phys. Discuss., https://doi.org/10.5194/acp-2019-251

Manuscript under review for journal Atmos. Chem. Phys.

Discussion started: 17 April 2019

(c) Author(s) 2019. CC BY 4.0 License.

Atmospheric

Chemistry

and Physics

Discussions

Pöhlker et al., 2012; Savage et al., 2017). For all LIF data, mean FBAP number concentrations were integrated from either $0.8 \mu \mathrm{m}$ to $15 \mu \mathrm{m}$ or $1.0 \mu \mathrm{m}$ to $20 \mu \mathrm{m}$ and are reported for each of the 17 geographic locations (see Fig. 5 ) in Table 3 for a comparison with our simulated mean number concentrations of fungal spores and bacteria. The FBAP observations show a peak in the number distribution at about $1-4 \mu \mathrm{m}$, irrespective of location or 5 instrument. It has been previously suggested for several geographic locations that the UV-APS and WIBS FL3 channel may yield lower limit proxies for fungal spores, due in part to the large number concentration of spores in this size range compared to other biological particles (Gosselin et al., 2016; Healy et al., 2014). The sizes of modeled bacteria-containing and fungal spores particles considered in this study are consistent with this observed size range of peak FBAP concentrations $(1-4 \mu \mathrm{m})$, enabling a more accurate comparison.

10

\section{Results}

\subsection{Concentrations of modeled fungal spores}

15 The total global emissions calculated here with $\mathrm{HO} 5$ and $\mathrm{HO}, 17 \mathrm{Tg}^{-1}{ }^{-1}$ (see Table 1) corresponding to an average mass emission flux of $2.5 \mathrm{ng} \mathrm{m}^{-2} \mathrm{~s}^{-1}$, are within the range of uncertainties reported by Després et al. (2012) and Fröhlich-Nowoisky et al. (2016). Using the same HO5 parameterization, Heald and Spracklen (2009) and Hoose et al. (2010) calculated higher totals, $28 \mathrm{Tg} \mathrm{yr}^{-1}$ and $31 \mathrm{Tg} \mathrm{yr}^{-1}$, respectively. Nevertheless, calculations by Heald and Spracklen (2009) include not only the coarse mode (including a diameter of $5 \mu \mathrm{m}$, similar to HO5) but also a fine mode for particles of a diameter lower than $2.5 \mu \mathrm{m}$. This demonstrates the model sensitivity to the leaf area index dataset used in each study and the specific humidity calculated by each model.

The total global emissions calculated using SD and $\mathrm{HU}$ are about $48{\mathrm{Tg} \mathrm{yr}^{-1}}^{1}$ and $77 \mathrm{Tg} \mathrm{yr}^{-1}$, respectively. These stronger emissions lead to higher mean mass concentrations $\left(\sim 1.1 \mu \mathrm{g} \mathrm{m}^{-3}\right.$ for both the SD and HU parametrizations) as compared with $\mathrm{H} 03$ and $\mathrm{H} 05$ (see Table 1); and the characteristic magnitude reported in the literature.

Figures 2 and 3 show the spatial distribution of the annual mean fungal spore emission fluxes and number concentrations at the surface as simulated by all parametrizations. HO5 and HO3 show similar distributions but with higher number magnitude for $\mathrm{HO} 3$ because of the difference of the scaling mass factor due to the particle size. Whereas $\mathrm{HO} 5 / \mathrm{HO} 3$ and $\mathrm{HU}$ result in highest values over the Amazon and tropical Africa, SD does not yield maximum values in these regions and simulates much larger emission Further, the comparison of fungal spore number fluxes calculated by Sesartic and Dallafior (2011) and by EMAC yields large discrepancies in magnitude and spatial distribution. This is most likely explained by large differences in the biome spatial distribution between MODIS and Olson data, leading to the higher emissions calculated by EMAC when using the SD parameterization. Interestingly, the spatial distributions of $\mathrm{HU}$ emission fluxes and concentrations are not restricted to land as for the 
Atmos. Chem. Phys. Discuss., https://doi.org/10.5194/acp-2019-251

Manuscript under review for journal Atmos. Chem. Phys.

Discussion started: 17 April 2019

(c) Author(s) 2019. CC BY 4.0 License.

Atmospheric

Chemistry

and Physics

Discussions

other parameterizations and have been extended to all ecosystems. This leads to the highest totals, as indicated in Table 1. Note that this parametrization has been optimized for a regional modeling study over northern Europe, and therefore is probably not suitable for use globally and for all ecosystems.

\section{3.2. Comparison of the EMAC fungal spore concentrations with direct measurements}

Our simulated, globally distributed, annual mean number concentrations of fungal spores obtained using the three emission parameterizations are compared to the set of spore counts at various locations in Figure 4. Observational data are differentiated by biome as defined by MODIS data, including the urban ecosystem. The concentrations are overestimated by all three parameterizations, but least by HO5. HO3 agrees better with observed spore counts with a correlation coefficient (R) of 0.24 and a median model-to-observation ratio of 6 for HO5, compared to 10 for HO3 and more than 100 for the other two parameterizations. Two additional metrics of the level of agreement between model results and observations are presented in Figure 4: the modified normalized mean bias (MNMB), a measure of bias that is symmetrical with respect to over-estimates and underestimates (ranging between -2 to 2 and equal to 0 for a "perfect" model), and the fractional gross error (FGE), a measure of the relative model error (ranging from 0 for a "perfect model" to a maximum value of 2), which behaves symmetrically with respect to under- and overestimation, without overemphasizing outliers (Huijnen and Eskes, 2012).

From the three parametrizations, HO5 performs best on all three scores. HO3 shows a similar correlation coefficient but higher MNMB and FGE than HO5. SD and HU show similar MNMB and FGE, but HU correlates slightly negatively with the observations. Although we compare local measurements limited in their representativeness in time and space to the relatively coarse grid size (approximately $140 \mathrm{~km}$ ) of the climatological model data, only the comparison with HO5 can be rated as satisfactory. Surprisingly, the SD derived fungal concentrations are the least comparable to observations despite the fact that the formulation of the emission parameterization is based partly on the same observations. This might be due to the change of the global ecosystem distribution, as we used the MODIS classification on which the HO5 parameterization was based, instead of the Olson distribution on which the SD parameterization was based. The HU emission parameterization might not be suited for use in global modeling studies since it was optimized for a regional modeling study over northern Europe. Differences in model physics, including the parameterizations of turbulent transport, precipitation, wet and dry removal, can also produce different concentrations, given the same emissions, so these results cannot necessarily be extended to other atmospheric models.

Discrepancies between model results and observations may be explained by an overprediction of fungal spore sources via biases in the emission parameterization or long-range transport, or an underprediction of the rate of 
Atmos. Chem. Phys. Discuss., https://doi.org/10.5194/acp-2019-251

Manuscript under review for journal Atmos. Chem. Phys.

Discussion started: 17 April 2019

(C) Author(s) 2019. CC BY 4.0 License.

Atmospheric

Chemistry

and Physics

Discussions

removal by dry and wet deposition. Additionally, as outlined by Sesartic and Dallafior (2011) and references therein, the observational data quality is limited and should be considered with caution. The methods used to measure actual spore concentrations may involve biases, e.g. problems related to the identification of fungal spores. As mentioned in section 2.3.1, (Sesartic and Dallafior, 2011) showed that many direct-counting spore techniques

5 can significantly undercount spore number (i.e. by orders of magnitude). Additionally, any culture-based methods have significant biases in that only a very small fraction of spore species can be culturable in a given medium.

Since the HO simulations agree most closely with observations, we will show results only from this simulation hereafter.

10

\subsection{Correlation between direct measurements and meteorological parameters}

Meteorological variables affect the initial release of fungal spores into the atmosphere and their dispersal once airborne. Temperature and humidity affect the size of the source and control the release of most actively released

15 fungal spores, where some species emit spores primarily during cool and wet conditions and other emit during warm and dry conditions (Jones and Harrison, 2004). The spore concentration and frequency of emission are equally dependent on geographical characteristics. Further, rainfall has been shown to correlate with fungal spore and other PBAP emission properties, leading to substantial local increases in short bursts during and following rain (Joung et al., 2017; Rathnayake et al., 2017). Since the publications collected for this study do not always provide information on the meteorological parameters of the observational site, we investigate the effects of physical parameters such as temperature, specific humidity, and leaf area index, as modeled by EMAC, on the observed particle concentrations, taking into account the differentiation between ecosystems as defined by MODIS data. Interestingly, we find a strong difference between non-urban and urban observations through their correlations with the three parameters. Table 2 shows a correlation coefficient of 0.41 between the observations and specific 25 humidity for the urban points and the same correlation between the non-urban observations and the leaf area index. This demonstrates the stronger effect of meteorological variables on urban sites, which could be taken into account in the formulation of a more advanced fungal spore emission parameterization. Additional observational evidence is needed to support this hypothesis.

\subsection{Comparison of the EMAC simulated fungal spores and bacteria with FBAP observations}

Figure 5 shows a comparison between the observed FBAP number concentrations and the modeled concentrations of bacteria and fungal spores using $\mathrm{HO} 5$ in Figure 5A and HO3 in Figure 5B. The comparison excludes data from Nanjing, China $\left(\sim 2 \times 10^{6} \mathrm{~m}^{-3}\right)$, because the observed particle counts were approximately two orders of magnitude 
Atmos. Chem. Phys. Discuss., https://doi.org/10.5194/acp-2019-251

Manuscript under review for journal Atmos. Chem. Phys.

Discussion started: 17 April 2019

(c) Author(s) 2019. CC BY 4.0 License.

Atmospheric

Chemistry

and Physics

Discussions

higher than concentrations observed elsewhere, likely as a result of urban pollution influence. For the locations Saclay and Killaney, both UV-APS and WIBS observations are available, though, for the sake of clarity, only WIBS data are shown in Figure 5.

5 In general, the $\mathrm{HO} 5$ and $\mathrm{HO} 3$ model results compare relatively well with the observations of total fluorescent particles in almost all locations. The HO5 model concentrations are lower than FBAP concentrations in ca. $40 \%$ of the observations and are within a factor of two (high or low) in all cases. This model underprediction is largest in the summer season. The HO3 model concentrations. alternatively, are higher by a factor of two to three than FBAP concentrations in almost $95 \%$ of the locations. This is due to the higher number concentrations simulated using

$10 \mathrm{HO} 3$ than HO5, illustrated in Figure 5B. The model predicts higher bacteria loadings than fungal spores in almost all cases, with the only exceptions of Ucluelet (rural coastal) and the Amazon (near-pristine tropical forest) using $\mathrm{HO} 5$ and HO3. Additionally, the simulated bacteria number concentrations in Figure 5 dominate the total PBAP concentrations for the locations where observations are available in winter, when very low concentrations of fungal spores are expected. A possible explanation for this discrepancy is that bacteria emissions are assumed constant in

15 time, representing inferred "background" emissions, while they may exhibit seasonal variations not taken into account in our model. Consequently, the differences in the seasonal bacteria concentrations for each location are related to transport and deposition patterns reproduced in the model. Fungal spore emissions, in contrast, are assumed to include seasonal variability due to the seasonality of the leaf area index and the specific humidity, which are used as model inputs. Many reports support the observed seasonal cycle of fungal spore concentrations, which are typically highest in summer and early fall, but depends on latitude and ecosystem (Lacey, 1996; Lang-

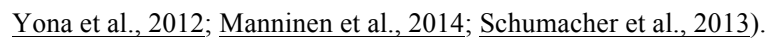

Laboratory-based observations have shown that the WIBS FL3 channel utilized here is less efficient at detecting bacteria (Hernandez et al., 2016; Savage et al., 2017) and thus is likely to detect fungal spores or pollen with 25 relatively higher efficiency. The large size of pollen grains limits their ability to be detected by the WIBS, however, and so fungal spores are assumed to represent the largest fraction of biological particles detected by the WIBS FL3 channel. Moreover, evidence in certain campaigns suggests that these fluorescence channels correlate well with fungal spores (e.g., (Fernandez-Rodriguez et al., 2018; Healy et al., 2014; Huffman et al., 2012)). Other important technical considerations were discussed in Section 2.3.2. In particular, note that our comparison here including the bacteria-containing particle concentrations is only qualitative, as their contribution to the total FBAP observations as utilized here is unclear. We include bacteria-containing particles in our comparison in order to emphasize the uncertainty they contribute to any direct comparison between FBAP and fungal spores. 
Atmos. Chem. Phys. Discuss., https://doi.org/10.5194/acp-2019-251

Manuscript under review for journal Atmos. Chem. Phys.

Discussion started: 17 April 2019

(c) Author(s) 2019. CC BY 4.0 License.

Atmospheric

Chemistry

and Physics

Discussions

Therefore, the differentiation between $\mathrm{HO} 5$ and $\mathrm{HO} 3$ fungal spore concentrations is relevant in the comparison. If we consider that the FBAPs observed in these locations mainly represent fungal spores, HO5 shows an underestimation compared to FBAP at all stations, while $\mathrm{HO} 3$ shows an underestimation at only $50 \%$ of the stations. In both cases, the simulated fungal spores occur at lowest concentrations during the winter season, and in

5 the case of $\mathrm{HO} 3$ concentrations are also low in spring and fall. For HO3, the concentrations are overestimated, especially in the summer when they are a factor of two higher than observations. This contradicts the results presented in Section 3.2, which shows a modeled overestimation (by a factor of 6 and 10) with respect to spore counts measured by optical microscopy (Figure 4). As mentioned, the comparison of modeled fungal spores with direct counts of spores may also be biased because of model inputs and the frequently observed undercounting of spore by some collection and detection methods. FBAP and spore counts measured via optical microscopy were compared for two sets of new measurements shown here (Saclay and Cyprus). The observed values from each method are reported here with the relative factor that the FBAP concentration overcounts the spore counts from the optical technique shown in parentheses: Saclay - $0.048 \times 10^{6} \mathrm{~m}^{-3}$ (spore count), $0.088 \times 10^{6} \mathrm{~m}^{-3}$ (WIBS-4A; $\mathrm{x} 1.8$ ), and $0.027 \times 10^{6} \mathrm{~m}^{-3}$ (UV-APS; x0.6); Cyprus - $0.0015 \times 10^{6} \mathrm{~m}^{-3}$ (spore count), and $0.0433 \times 10^{6} \mathrm{~m}^{-3}$ (WIBS-4A;

15 x29). In several other cases, collocated measurements of FBAP and spore counts also show spore count to be lower than FBAP by a factor of $\sim 2$ (Fernandez-Rodriguez et al., 2018) to $\sim 10$ (Healy et al., 2014; Huffman et al., 2012), again depending partially on instrumental parameters and differences in observed bioaerosols. Quantitative differences are a combination of undercounting of spores by direct measurements and counting of non-spore particles (bacteria and some non-biological particles) by FBAP measurements. Additional direct comparison of FBAP concentrations with spore count concentrations summarized in this study (Table SI1 and Fig. 1) is not possible because of differences in locations and seasons. Therefore, the qualitative relationship between UV-LIF and other spore counting techniques has been demonstrated, but quantitative comparisons often show significant differences.

Significant uncertainties also remain in the interpretation of the UV-LIF measurements. For example, UV-LIF

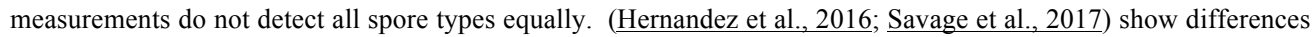
in fluorescence profiles of a number of spore types and discuss that different instrument units detect particles with different detection efficiencies. This implies that both biological and instrumental factors can lead to differences in observed FBAP concentrations. (Healy et al., 2014; Huffman et al., 2012) both discuss how certain types of spores may escape detection. In particular, (Fernandez-Rodriguez et al., 2018; Healy et al., 2014) discuss how the genus Cladosporium (among the most commonly observed spore type in many environments) correlated very poorly with fluorescent measurements, suggesting that dark-walled cell walls present in this type of spores may inhibit some types of real-time fluorescence detection. This spore type is a dominant spore type during dry weather, therefore it might be undercounted during the day and in certain locations where such spore types are a high fraction of the 
Atmos. Chem. Phys. Discuss., https://doi.org/10.5194/acp-2019-251

Manuscript under review for journal Atmos. Chem. Phys.

Discussion started: 17 April 2019

(c) Author(s) 2019. CC BY 4.0 License.

Atmospheric

Chemistry

and Physics

Discussions

spore number. In some cases the FL3 signal is also influenced by non-biological particles (Savage et al., 2017), and so FBAP number concentrations from WIBS and UV-APS presented here should be used only for a rough comparison.

\section{4. Discussion and Conclusions}

We used the chemistry-climate model EMAC to simulate the total PBAPs present in the atmosphere including bacteria, but with a focus on fungal spores. We compared the simulated fungal spore number concentrations, simulated using three emission parameterizations, to an updated data set of spore counts synthesized from the literature. Additional evaluation of the modeled simulated PBAP concentrations was performed using a comparison with a global data set of FBAP concentrations.

Among the four fungal spore emission schemes examined here, the HO5 parameterization using a fixed spore diameter of $5 \mu \mathrm{m}$ showed the best fit to observations, although the model overpredicts the concentrations by up to a

15 factor of 6 in some locations. Using the same parameterization (after rescaling), HO3 with a diameter of $3 \mu \mathrm{m}$ showed a larger overprediction. Spore count observations are limited in time and space and are subject to several methodological issues. Therefore, these direct-count measurements cannot provide a rigorous evaluation of the model results. Bacteria and fungal spore concentrations predicted by the model agree well with FBAP observations from real-time measurement techniques. The overprediction/underprediction is estimated to be of a factor of 2 or less for all measurement locations. Modeled bacteria concentrations exceed fungal spores in most locations, particularly in winter, while simulated fungal spores might be underestimated/overestimated in near-pristine environments, depending on the diameter choice of the parametrization. The FBAP concentrations used here (from UV-APS data and WIBS-FL3 channel) are likely to underestimate fungal spores somewhat, and dramatically underrate the abundance of bacteria in most locations. Most bacteria are not strongly fluorescent in the applied 25 wavelength channels and are therefore underestimated. This might explain the differences when we expect high bacterial counts, e.g. (Savage et al., 2017).

In general, the $\mathrm{HO} 3$ and $\mathrm{HO} 5$ parameterizations perform better than the $\mathrm{HU}$ and SD parameterizations, confirming that process-based parametrizations accomplish the best results. The differences between HO5 and HO3 emphasize the importance of the choice of the particle sizes in comparisons with observations, expressed in number concentrations and not in mass concentrations. This should be taken into account in the further development of emission parameterizations for fungal spores. New parametrizations should consider a range of particle sizes, as the size and mass are usually not measured in observations of atmospheric fungal spores, and remain highly uncertain. 
Atmos. Chem. Phys. Discuss., https://doi.org/10.5194/acp-2019-251

Manuscript under review for journal Atmos. Chem. Phys.

Discussion started: 17 April 2019

(c) Author(s) 2019. CC BY 4.0 License.

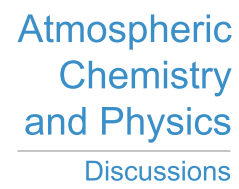

ग

(c) (i)

Our calculated correlations between observed spore counts and meteorological parameters confirm the seasonal leaf area index as the main factor driving fungal spore emissions in non-urban areas, while the specific humidity controls the emissions in urban areas. Additional measurements of the meteorological parameters during periods of observations are needed to confirm this hypothesis. This might also contribute to a differentiation between urban

5 and non-urban areas in the emission fluxes, to be considered by models in the future.

In conclusion, fungal spore concentrations are underestimated by the EMAC model in most locations with respect to the FBAP data used, but overestimated with respect to direct count observations of spores. The bacteria emission scheme we applied does not represent seasonal nor diurnal variability, a weakness that needs to be addressed in

future work. Further comparisons of modeled results with long-term FBAP measurements, taking into account daily and seasonal variability, might offer new opportunities to better constraint our model emission parameterizations. Improvements in the way FBAP data are analyzed will also allow for better separation of bacteria and fungal spores and will thus allow for better comparison with improved models in the future (Ruske et al., 2017). 
Atmos. Chem. Phys. Discuss., https://doi.org/10.5194/acp-2019-251

Manuscript under review for journal Atmos. Chem. Phys.

Discussion started: 17 April 2019

(c) Author(s) 2019. CC BY 4.0 License.

\section{Author Contribution}

MT and SMB designed the research study and AP, JAH, SB, MT carried it out. MT and SB did the model simulations. AP contributed to the model data processing. KMP, NJB and RSE and JAH provided the FBAP data.

5 JL discussed the results and contributed to the final manuscript.

\section{Acknowledgments}

We acknowledge the CEA/DAM/CBRN-E research programs and D. Baisnée (CEA) for providing the spore counts for Saclay and Cyprus. Unpublished WIBS measurements summarized in Table 2 were made possible through collaboration with many partners, including the following details. Measurements performed in Cyprus were partly supported by the EU-H2020 ACTRIS-2 project (European Union's Horizon 2020 research and innovation program, grant agreement No 654109) and the EU FP7-ENV-2013 BACCHUS project (grant Agreement 603445). Measurements in Ucluelet, Canada were led by Jixiao Li (Univ. Denver) and Ryan Mason (Univ. British 15 Columbia) as a part of a NETCARE study (Mason et al., 2015) organized by Allan Bertram (Univ. British Columbia) and Jon Abbatt (Univ. Toronto) and with financial support from the NSERC CCAR program and from Environment Canada. Measurements in Barbados were organized and supported by the Max Planck Institute for Chemistry (Ulrich Pöschl), the University of Miami (Joseph Prospero), the Caribbean Institute for Meteorology and Hydrology (David Farrell), and were made possible with help from Christine Krentz (Univ. Denver), Mira Pöhlker, Bettina Weber, Maria Praß, Florian Ditas, Thomas Klimach, Petya Yordanova, and Christopher Pöhlker (all Max Planck Institute for Chemistry). ). UV-APS measurements in Paris (2010) in Paris were performed as a part of the MEGAPOLI campaign by Johannes Schneider (Max Planck Institute for Chemistry). Measurements in Saclay, France were performed as a part of the Biodetect 2014 study supported by CEA/DAM/CBRN-E, with assistance by Walfried Lassar (Univ. Denver). The authors gratefully acknowledge the stimulating discussions and exchange with Ulrich Pöschl and the Mainz Bioaerosol Laboratory. We thank Ulrich Pöschl, and Christopher Pöhlker for their critical reading of the manuscript. The University of Denver is acknowledged for financial support for Nicole Savage through the Phillipson Graduate Fellowship and for Kyle Pierce through a grant from the Undergraduate Research Center. 
Atmos. Chem. Phys. Discuss., https://doi.org/10.5194/acp-2019-251

Manuscript under review for journal Atmos. Chem. Phys.

Discussion started: 17 April 2019

(c) Author(s) 2019. CC BY 4.0 License.

\section{References}

Bangert, M., Nenes, A., Vogel, B., Vogel, H., Barahona, D., Karydis, V. A., Kumar, P., Kottmeier, C., and Blahak, U.: Saharan dust event impacts on cloud formation and radiation over Western Europe, Atmospheric Chemistry and

5 Physics, 12, 4045-4063, 2012.

Burge, H. A. and Rogers, C. A.: Outdoor allergens, Environmental Health Perspectives, 108, 653-659, 2000.

Burrows, S. M., Butler, T., Jockel, P., Tost, H., Kerkweg, A., Pöschl, U., and Lawrence, M. G.: Bacteria in the global atmosphere - Part 2: Modeling of emissions and transport between different ecosystems, Atmospheric Chemistry and Physics, 9, 9281-9297, 2009a.

10 Burrows, S. M., Elbert, W., Lawrence, M. G., and Pöschl, U.: Bacteria in the global atmosphere - Part 1: Review and synthesis of literature data for different ecosystems, Atmospheric Chemistry and Physics, 9, 9263-9280, 2009b. Burrows, S. M., Rayner, P. J., Butler, T., and Lawrence, M. G.: Estimating bacteria emissions from inversion of atmospheric transport: sensitivity to modelled particle characteristics, Atmospheric Chemistry and Physics, 13, 5473-5488, 2013.

15 Bush, R. K. and Portnoy, J. M.: The role and abatement of fungal allergens in allergic diseases, J Allergy Clin Immunol, 107, S430-440, 2001.

Caruana, D. J.: Detection and analysis of airborne particles of biological origin: present and future, Analyst, 136, 4641-4652, 2011.

Christoudias, T. and Lelieveld, J.: Modelling the global atmospheric transport and deposition of radionuclides from the Fukushima Dai-ichi nuclear accident. , Atmospheric Chemistry and Physics, 13, 1425-1438, 2013.

Deguillaume, L., Leriche, M., Amato, P., Ariya, P. A., Delort, A. M., Pöschl, U., Chaumerliac, N., Bauer, H., Flossmann, A. I., and Morris, C. E.: Microbiology and atmospheric processes: chemical interactions of primary biological aerosols, Biogeosciences, 5, 1073-1084, 2008.

DeMott, P. J., Prenni, A. J., Liu, X., Kreidenweis, S. M., Petters, M. D., Twohy, C. H., Richardson, M. S., Eidhammer, T., and Rogers, D. C.: Predicting global atmospheric ice nuclei distributions and their impacts on climate, Proceedings of the National Academy of Sciences of the United States of America, 107, 11217-11222, 2010.

Deng, F., Chen, J. M., Plummer, S., Chen, M. Z., and Pisek, J.: Algorithm for global leaf area index retrieval using satellite imagery, Ieee T Geosci Remote, 44, 2219-2229, 2006.

Després, V. R., Huffman, J. A., Burrows, S. M., Hoose, C., Safatov, A. S., Buryak, G., Fröhlich-Nowoisky, J., Elbert, W., Andreae, M. O., Pöschl, U., and Jaenicke, R.: Primary biological aerosol particles in the atmosphere: a review, Tellus B; Vol 64 (2012), 2012. 2012. 
Atmos. Chem. Phys. Discuss., https://doi.org/10.5194/acp-2019-251

Manuscript under review for journal Atmos. Chem. Phys.

Discussion started: 17 April 2019

(c) Author(s) 2019. CC BY 4.0 License.

Elbert, W., Taylor, P. E., Andreae, M. O., and Pöschl, U.: Contribution of fungi to primary biogenic aerosols in the atmosphere: Wet and dry discharged spores, carbohydrates, and inorganic ions, Atmospheric Chemistry and Physics, 7, 4569-4588, 2007.

Fennelly, M. J., Sewell, G., Prentice, M. B., O'Connor, D. J., and Sodeau, J. R.: Review: The Use of Real-Time

5 Fluorescence Instrumentation to Monitor Ambient Primary Biological Aerosol Particles (PBAP), Atmosphere, 9, 2018.

Fernandez-Rodriguez, S., Tormo-Molina, R., Lemonis, N., Clot, B., O'Connor, D. J., and Sodeau, J. R.: Comparison of fungal spores concentrations measured with wideband integrated bioaerosol sensor and Hirst methodology, Atmospheric Environment, 175, 1-14, 2018.

10 Foot, E. V., Kaye, P. H., Stanley, W. R., Barrington, S. J., Gallagher, M., and Gabey, A. M.: Low-cost real-time multi-parameter bio-aerosol sensors, 2008.

French, J. R., Friedrich, K., Tessendorf, S. A., Rauber, R. M., Geerts, B., Rasmussen, R. M., Xue, L. L., Kunkel, M. L., and Blestrud, D. R.: Precipitation formation from orographic cloud seeding, Proceedings of the National Academy of Sciences of the United States of America, 115, 1168-1173, 2018.

15 Fröhlich-Nowoisky, J., Kampf, C. J., Weber, B., Huffman, J. A., Pöhlker, C., Andreae, M. O., Lang-Yona, N., Burrows, S. M., Gunthe, S. S., Elbert, W., Su, H., Hoor, P., Thines, E., Hoffmann, T., Despres, V. R., and Pöschl, U.: Bioaerosols in the Earth system: Climate, health, and ecosystem interactions, Atmos Res, 182, 346-376, 2016. Fröhlich-Nowoisky, J., Pickersgill, D. A., Despres, V. R., and Pöschl, U.: High diversity of fungi in air particulate matter, Proceedings of the National Academy of Sciences of the United States of America, 106, 12814-12819, 2009.

Gabey, A. M., Gallagher, M. W., Whitehead, J., Dorsey, J. R., Kaye, P. H., and Stanley, W. R.: Measurements and comparison of primary biological aerosol above and below a tropical forest canopy using a dual channel fluorescence spectrometer, Atmospheric Chemistry and Physics, 10, 4453-4466, 2010.

Gabey, A. M., Stanley, W. R., Gallagher, M. W., and Kaye, P. H.: The fluorescence properties of aerosol larger than $0.8 \mathrm{mu} \mathrm{m}$ in urban and tropical rainforest locations, Atmospheric Chemistry and Physics, 11, 5491-5504, 2011.

Gabey, A. M., Vaitilingom, M., Freney, E., Boulon, J., Sellegri, K., Gallagher, M. W., Crawford, I. P., Robinson, N. H., Stanley, W. R., and Kaye, P. H.: Observations of fluorescent and biological aerosol at a high-altitude site in central France, Atmospheric Chemistry and Physics, 13, 7415-7428, 2013.

30 Glaser, G., Kerkweg, A., and Wernli, H.: The Mineral Dust Cycle in EMAC 2.40: sensitivity to the spectral resolution and the dust emission scheme, Atmospheric Chemistry and Physics, 12, 1611-1627, 2012.

Gosselin, M. I., Rathnayake, C. M., Crawford, I., Pohlker, C., Frohlich-Nowoisky, J., Schmer, B., Despres, V. R., Engling, G., Gallagher, M., Stone, E., Pöschl, U., and Huffman, J. A.: Fluorescent bioaerosol particle, molecular 
Atmos. Chem. Phys. Discuss., https://doi.org/10.5194/acp-2019-251

Manuscript under review for journal Atmos. Chem. Phys.

Discussion started: 17 April 2019

(c) Author(s) 2019. CC BY 4.0 License.

tracer, and fungal spore concentrations during dry and rainy periods in a semi-arid forest, Atmospheric Chemistry and Physics, 16, 15165-15184, 2016.

Green, B. J., Sercombe, J. K., and Tovey, E. R.: Fungal fragments and undocumented conidia function as new aeroallergen sources, Journal of Allergy and Clinical Immunology, 115, 1043-1048, 2005.

5 Griffiths, W. D. and Decosemo, G. A. L.: The Assessment of Bioaerosols - a Critical-Review, J Aerosol Sci, 25, 1425-1458, 1994.

Grinn-Gofron, A. and Bosiacka, B.: Effects of meteorological factors on the composition of selected fungal spores in the air, Aerobiologia (Bologna), 31, 63-72, 2015.

Hairston, P. P., Ho, J., and Quant, F. R.: Design of an instrument for real-time detection of bioaerosols using

10 simultaneous measurement of particle aerodynamic size and intrinsic fluorescence, J Aerosol Sci, 28, 471-482, 1997.

Heald, C. L. and Spracklen, D. V.: Atmospheric budget of primary biological aerosol particles from fungal spores, Geophysical Research Letters, 36, 2009.

Healy, D. A., Huffman, J. A., O'Connor, D. J., Pohlker, C., Pöschl, U., and Sodeau, J. R.: Ambient measurements

of biological aerosol particles near Killarney, Ireland: a comparison between real-time fluorescence and microscopy techniques, Atmospheric Chemistry and Physics, 14, 8055-8069, 2014.

Hernandez, M., Perring, A. E., McCabe, K., Kok, G., Granger, G., and Baumgardner, D.: Chamber catalogues of optical and fluorescent signatures distinguish bioaerosol classes, Atmos Meas Tech, 9, 3283-3292, 2016.

Hirst, J. M.: Changes in atmospheric spore content: Diurnal periodicity and the effects of weather, Transactions of the British Mycological Society, 36, 375-393, 1953.

Hoose, C., Kristjánsson, J. E., and Burrows, S. M.: How important is biological ice nucleation in clouds on a global scale?, Environmental Research Letters, 5, 2010.

Huffman, J. A., Prenni, A. J., DeMott, P. J., Pohlker, C., Mason, R. H., Robinson, N. H., Frohlich-Nowoisky, J., Tobo, Y., Despres, V. R., Garcia, E., Gochis, D. J., Harris, E., Mueller-Germann, I., Ruzene, C., Schmer, B., Sinha, B., Day, D. A., Andreae, M. O., Jimenez, J. L., Gallagher, M., Kreidenweis, S. M., Bertram, A. K., and Pöschl, U.: High concentrations of biological aerosol particles and ice nuclei during and after rain, Atmospheric Chemistry and Physics, 13, 6151-6164, 2013.

Huffman, J. A. and Santarpia, J.: Online Techniques for Quantification and Characterization of Biological Aerosols. In: Microbiology of Aerosols, John Wiley \& Sons, Inc., 2017.

Huffman, J. A., Sinha, B., Garland, R. M., Snee-Pollmann, A., Gunthe, S. S., Artaxo, P., Martin, S. T., Andreae, M. O., and Pöschl, U.: Size distributions and temporal variations of biological aerosol particles in the Amazon rainforest characterized by microscopy and real-time UV-APS fluorescence techniques during AMAZE-08, Atmospheric Chemistry and Physics, 12, 11997-12019, 2012. 
Atmos. Chem. Phys. Discuss., https://doi.org/10.5194/acp-2019-251

Manuscript under review for journal Atmos. Chem. Phys.

Discussion started: 17 April 2019

(c) Author(s) 2019. CC BY 4.0 License.

Atmospheric

Chemistry

and Physics

Discussions

Huffman, J. A., Treutlein, B., and Poschl, U.: Fluorescent biological aerosol particle concentrations and size distributions measured with an Ultraviolet Aerodynamic Particle Sizer (UV-APS) in Central Europe, Atmospheric Chemistry and Physics, 10, 3215-3233, 2010.

Huijnen, V. and Eskes, H.: Skill scores and evaluation methodology for the MACC II project, 2012.

5 Hummel, M., ; Hoose, C.; Pummer, B.; Schaupp, C. E. ; Fröhlich-Nowoisky, J.; and Möhler, O.: Simulating the Influence of Primary Biological Aerosol Particles on Clouds by Heterogeneous Ice Nucleation, Atmos. Chem. Phys. Discuss., doi: https://doi.org/10.5194/acp-2018-182, 2018. 2018.

Hummel, M., Hoose, C., Gallagher, M., Healy, D. A., Huffman, J. A., O'Connor, D., Pöschl, U., Pöhlker, C., Robinson, N. H., Schnaiter, M., Sodeau, J. R., Stengel, M., Toprak, E., and Vogel, H.: Regional-scale simulations

10 of fungal spore aerosols using an emission parameterization adapted to local measurements of fluorescent biological aerosol particles, Atmospheric Chemistry and Physics, 15, 6127-6146, 2015.

Jacobson, M. Z. and Streets, D. G.: Influence of future anthropogenic emissions on climate, natural emissions, and air quality, J Geophys Res-Atmos, 114, 2009.

Jöckel, P., Sander, R., Kerkweg, A., Tost, H., and Lelieveld, J.: Technical note: The Modular Earth Submodel

15 System (MESSy) - a new approach towards Earth System Modeling, Atmospheric Chemistry and Physics, 5, 433444, 2005.

Jöckel, P., Tost, H., Pozzer, A., Kunze, M., Kirner, O., Brenninkmeijer, C. A. M., Brinkop, S., Cai, D. S., Dyroff, C., Eckstein, J., Frank, F., Garny, H., Gottschaldt, K. D., Graf, P., Grewe, V., Kerkweg, A., Kern, B., Matthes, S., Mertens, M., Meul, S., Neumaier, M., Nutzel, M., Oberlander-Hayn, S., Ruhnke, R., Runde, T., Sander, R.,

20 Scharffe, D., and Zahn, A.: Earth System Chemistry integrated Modelling (ESCiMo) with the Modular Earth Submodel System (MESSy) version 2.51, Geosci Model Dev, 9, 1153-1200, 2016.

Jones, A. M. and Harrison, R. M.: The effects of meteorological factors on atmospheric bioaerosol concentrations-a review, Sci Total Environ, 326, 151-180, 2004

Joung, Y. S., Ge, Z., and Buie, C. R.: Bioaerosol generation by raindrops on soil, Nat Commun, 8, 14668, 2017.

25 Kaye, P. H., Stanley, W. R., Hirst, E., Foot, E. V., Baxter, K. L., and Barrington, S. J.: Single particle multichannel bio-aerosol fluorescence sensor, Opt Express, 13, 3583-3593, 2005.

Kerkweg, A., Buchholz, J., Ganzeveld, L., Pozzer, A., Tost, H., and Jockel, P.: Technical note: An implementation of the dry removal processes DRY DEPosition and SEDImentation in the modular earth submodel system (MESSy), Atmospheric Chemistry and Physics, 6, 4617-4632, 2006.

30 Lacey, J.: 13 - The Aerobiology of Conidial Fungi A2 - Cole, Garry T. In: Biology of Conidial Fungi, Kendrick, B. (Ed.), Academic Press, 1981.

Lacey, J.: Spore dispersal - Its role in ecology and disease: The British contribution to fungal aerobiology, Mycological Research, 100, 641-660, 1996. 
Atmos. Chem. Phys. Discuss., https://doi.org/10.5194/acp-2019-251

Manuscript under review for journal Atmos. Chem. Phys.

Discussion started: 17 April 2019

(c) Author(s) 2019. CC BY 4.0 License.

Atmospheric

Chemistry

and Physics

Discussions

Lang-Yona, N., Dannemiller, K., Yamamoto, N., Burshtein, N., Peccia, J., Yarden, O., and Rudich, Y.: Annual distribution of allergenic fungal spores in atmospheric particulate matter in the Eastern Mediterranean; a comparative study between ergosterol and quantitative PCR analysis, Atmospheric Chemistry and Physics, 12, 2681-2690, 2012.

5 Lelieveld, J., Kunkel, D., and Lawrence, M. G.: Global risk of radioactive fallout after major nuclear reactor accidents, Atmospheric Chemistry and Physics, 12, 4245-4258, 2012.

Levetin, E. and Dorsey, K.: Contribution of leaf surface fungi to the air spora, Aerobiologia, 22, 3-12, 2006.

Li, D. W. and Kendrick, B.: A Year-Round Study on Functional-Relationships of Airborne Fungi with Meteorological Factors, International Journal of Biometeorology, 39, 74-80, 1995.

10 Manninen, H. E., Back, J., Sihto-Nissila, S. L., Huffman, J. A., Pessi, A. M., Hiltunen, V., Aalto, P. P., Hidalgo, P. J., Hari, P., Saarto, A., Kulmala, M., and Petaja, T.: Patterns in airborne pollen and other primary biological aerosol particles (PBAP), and their contribution to aerosol mass and number in a boreal forest, Boreal Environ Res, 19, 383-405, 2014.

Mason, R. H., Si, M., Li, J., Chou, C., Dickie, R., Toom-Sauntry, D., Pohlker, C., Yakobi-Hancock, J. D., Ladino,

15 L. A., Jones, K., Leaitch, W. R., Schiller, C. L., Abbatt, J. P. D., Huffman, J. A., and Bertram, A. K.: Ice nucleating particles at a coastal marine boundary layer site: correlations with aerosol type and meteorological conditions, Atmospheric Chemistry and Physics, 15, 12547-12566, 2015.

O'Connor, D. J., Iacopino, D., Healy, D. A., O'Sullivan, D., and Sodeau, J. R.: The intrinsic fluorescence spectra of selected pollen and fungal spores, Atmospheric Environment, 45, 6451-6458, 2011.

20 Oliveira, M., Ribeiro, H., Delgado, J. L., and Abreu, I.: Seasonal and intradiurnal variation of allergenic fungal spores in urban and rural areas of the North of Portugal, Aerobiologia, 25, 85-98, 2009.

Olson, D. M., Dinerstein, E., Wikramanayake, E. D., Burgess, N. D., Powell, G. V. N., Underwood, E. C., D'Amico, J. A., Itoua, I., Strand, H. E., Morrison, J. C., Loucks, C. J., Allnutt, T. F., Ricketts, T. H., Kura, Y., Lamoreux, J. F., Wettengel, W. W., Hedao, P., and Kassem, K. R.: Terrestrial ecoregions of the worlds: A new 25 map of life on Earth, Bioscience, 51, 933-938, 2001.

Pan, Y. L., Pinnick, R. G., Hill, S. C., and Chang, R. K.: Particle-Fluorescence Spectrometer for Real-Time SingleParticle Measurements of Atmospheric Organic Carbon and Biological Aerosol, Environ Sci Technol, 43, 429-434, 2009.

Perring, A. E., Schwarz, J. P., Baumgardner, D., Hernandez, M. T., Spracklen, D. V., Heald, C. L., Gao, R. S.,

Kok, G., McMeeking, G. R., McQuaid, J. B., and Fahey, D. W.: Airborne observations of regional variation in fluorescent aerosol across the United States, J Geophys Res-Atmos, 120, 1153-1170, 2015.

Pöhlker, C., Huffman, J. A., and Pöschl, U.: Autofluorescence of atmospheric bioaerosols - fluorescent biomolecules and potential interferences, Atmos Meas Tech, 5, 37-71, 2012. 
Atmos. Chem. Phys. Discuss., https://doi.org/10.5194/acp-2019-251

Manuscript under review for journal Atmos. Chem. Phys.

Discussion started: 17 April 2019

(c) Author(s) 2019. CC BY 4.0 License.

Pozzer, A., de Meij, A., Pringle, K. J., Tost, H., Doering, U. M., van Aardenne, J., and Lelieveld, J.: Distributions and regional budgets of aerosols and their precursors simulated with the EMAC chemistry-climate model, Atmospheric Chemistry and Physics, 12, 961-987, 2012.

Prenni, A. J., Harrington, J. Y., Tjernstrom, M., DeMott, P. J., Avramov, A., Long, C. N., Kreidenweis, S. M.,

5 Olsson, P. Q., and Verlinde, J.: Can ice-nucleating aerosols affect arctic seasonal climate?, B Am Meteorol Soc, 88, 541-+, 2007.

Pringle, K. J., Tost, H., Message, S., Steil, B., Giannadaki, D., Nenes, A., Fountoukis, C., Stier, P., Vignati, E., and Leieved, J.: Description and evaluation of GMXe: a new aerosol submodel for global simulations (v1), Geosci Model Dev, 3, 391-412, 2010.

10 Rathnayake, C. M., Metwali, N., Jayarathne, T., Kettler, J., Huang, Y., Thorne, P. S., O'Shaughnessy, P. T., and Stone, E. A.: Influence of rain on the abundance of bioaerosols in fine and coarse particles, Atmos. Chem. Phys., 17, 2459-2475, 2017.

Reinmuth-Selzle, K., Kampf, C. J., Lucas, K., Lang-Yona, N., Frohlich-Nowoisky, J., Shiraiwa, M., Lakey, P. S. J., Lai, S. C., Liu, F. B., Kunert, A. T., Ziegler, K., Shen, F. X., Sgarbanti, R., Weber, B., Bellinghausen, I., Saloga, J.,

15 Weller, M. G., Duschl, A., Schuppan, D., and Pöschl, U.: Air Pollution and Climate Change Effects on Allergies in the Anthropocene: Abundance, Interaction, and Modification of Allergens and Adjuvants, Environ Sci Technol, 51, 4119-4141, 2017.

Ruske, S., Topping, D. O., Foot, V. E., Kaye, P. H., Stanley, W. R., Crawford, I., Morse, A. P., and Gallagher, M. W.: Evaluation of machine learning algorithms for classification of primary biological aerosol using a new UV-LIF spectrometer, Atmos Meas Tech, 10, 695-708, 2017.

Saari, S., Niemi, J. V., Ronkko, T., Kuuluvainen, H., Jarvinen, A., Pirjola, L., Aurela, M., Hillamo, R., and Keskinen, J.: Seasonal and Diurnal Variations of Fluorescent Bioaerosol Concentration and Size Distribution in the Urban Environment, Aerosol Air Qual Res, 15, 572-581, 2015.

Saari, S., Reponen, T., and Keskinen, J.: Performance of Two Fluorescence-Based Real-Time Bioaerosol Detectors: BioScout vs. UVAPS, Aerosol Science and Technology, 48, 371-378, 2014.

Saari, S. E., Putkiranta, M. J., and Keskinen, J.: Fluorescence spectroscopy of atmospherically relevant bacterial and fungal spores and potential interferences, Atmospheric Environment, 71, 202-209, 2013.

Savage, N. J., Krentz, C. E., Konemann, T., Han, T. T., Mainelis, G., Pohlker, C., and Huffman, J. A.: Systematic characterization and fluorescence threshold strategies for the wideband integrated bioaerosol sensor (WIBS) using size-resolved biological and interfering particles, Atmos Meas Tech, 10, 4279-4302, 2017.

Schumacher, C. J., Pöhlker, C., Aalto, P., Hiltunen, V., Petaja, T., Kulmala, M., Pöschl, U., and Huffman, J. A.: Seasonal cycles of fluorescent biological aerosol particles in boreal and semi-arid forests of Finland and Colorado, Atmospheric Chemistry and Physics, 13, 11987-12001, 2013. 
Atmos. Chem. Phys. Discuss., https://doi.org/10.5194/acp-2019-251

Manuscript under review for journal Atmos. Chem. Phys.

Discussion started: 17 April 2019

(c) Author(s) 2019. CC BY 4.0 License.

Sesartic, A. and Dallafior, T. N.: Global fungal spore emissions, review and synthesis of literature data, Biogeosciences, 8, 1181-1192, 2011.

Sesartic, A., Lohmann, U., and Storelvmo, T.: Modelling the impact of fungal spore ice nuclei on clouds and precipitation, Environmental Research Letters, 8, 2013.

5 Shaffer, B. T. and Lighthart, B.: Survey of culturable airborne bacteria at four diverse locations in Oregon: Urban, rural, forest, and coastal, Microbial Ecol, 34, 167-177, 1997.

Sivaprakasam, V., Pletcher, T., Tucker, J. E., Huston, A. L., McGinn, J., Keller, D., and Eversole, J. D.: Classification and selective collection of individual aerosol particles using laser-induced fluorescence, Appl Optics, 48, B126-B136, 2009.

10 Spracklen, D. V. and Heald, C. L.: The contribution of fungal spores and bacteria to regional and global aerosol number and ice nucleation immersion freezing rates, Atmospheric Chemistry and Physics, 14, 9051-9059, 2014.

Tong, Y. Y. and Lighthart, B.: The annual bacterial particle concentration and size distribution in the ambient atmosphere in a rural area of the Willamette valley, Oregon, Aerosol Science and Technology, 32, 393-403, 2000.

Tong, Y. Y. and Lighthart, B.: Diurnal distribution of total and culturable atmospheric bacteria at a rural site,

15 Aerosol Science and Technology, 30, 246-254, 1999.

Toprak, E. and Schnaiter, M.: Fluorescent biological aerosol particles measured with the Waveband Integrated Bioaerosol Sensor WIBS-4: laboratory tests combined with a one year field study, Atmospheric Chemistry and Physics, 13, 225-243, 2013.

Tost, H., Jockel, P. J., Kerkweg, A., Sander, R., and Lelieveld, J.: Technical note: A new comprehensive

20 SCAVenging submodel for global atmospheric chemistry modelling, Atmospheric Chemistry and Physics, 6, 565574, 2006.

Valsan, A. E., Ravikrishna, R., Biju, C. V., Pohlker, C., Despres, V. R., Huffman, J. A., Pöschl, U., and Gunthe, S. S.: Fluorescent biological aerosol particle measurements at a tropical high-altitude site in southern India during the southwest monsoon season, Atmospheric Chemistry and Physics, 16, 9805-9830, 2016.

25 Wang, C. C., Fang, G. C., and Lee, L.: Bioaerosols study in central Taiwan during summer season, Toxicol Ind Health, 23, 133-139, 2007.

Yu, J., Hu, Q., Xie, Z., Kang, H., Li, M., Li, Z., and Ye, P.: Concentration and Size Distribution of Fungi Aerosol over Oceans along a Cruise Path during the Fourth Chinese Arctic Research Expedition, Atmosphere, 4, 337-348, 2013.

30 Yu, X. W., Wang, Z. B., Zhang, M. H., Kuhn, U., Xie, Z. Q., Cheng, Y. F., Poschl, U., and Su, H.: Ambient measurement of fluorescent aerosol particles with a WIBS in the Yangtze River Delta of China: potential impacts of combustion-related aerosol particles, Atmospheric Chemistry and Physics, 16, 11337-11348, 2016. 
Atmos. Chem. Phys. Discuss., https://doi.org/10.5194/acp-2019-251

Manuscript under review for journal Atmos. Chem. Phys.

Discussion started: 17 April 2019

(c) Author(s) 2019. CC BY 4.0 License.

(c) (i)

\begin{tabular}{|c|c|c|c|c|c|}
\hline & $\begin{array}{c}\text { Emission } \\
(\mathrm{Tg} / \mathrm{yr})\end{array}$ & Burden & Lifetime & Number concentrations & Mass concentrations \\
$(\mathrm{Gg})$ & $(\mathrm{days})$ & $\left(\mathrm{m}^{-3}\right)$ & 0.17 \\
\hline $\begin{array}{c}\text { Fungal spores HO } \\
(\mathrm{D}=5 \mu \mathrm{m})\end{array}$ & 17.58 & 85 & 1.2 & 2620 & 0.22 \\
\hline $\begin{array}{c}\text { Fungal spores HO } \\
(\mathrm{D}=3 \mu \mathrm{m})\end{array}$ & 17.58 & 82 & 1.7 & 15824 & 1.15 \\
\hline $\begin{array}{c}\text { Fungal spores HU } \\
(\mathrm{D}=3 \mu \mathrm{m})\end{array}$ & 77.47 & 423 & 2 & 81755 & 1.1 \\
\hline $\begin{array}{c}\text { Fungal spores SD } \\
(\mathrm{D}=3 \mu \mathrm{m})\end{array}$ & 48.09 & 223 & 1.6 & 77994 & $\sim 0.1-1^{\mathrm{a}}$ \\
\hline Literature estimates & $8-186^{\mathrm{a}}$ & $94^{\mathrm{b}}, 186^{\mathrm{c}}$ & $1.1^{\mathrm{b}}, 2.3^{\mathrm{c}}$ & $\sim 10^{3}-10^{4 \mathrm{a}}$ & \\
\hline
\end{tabular}

Literature values are from ${ }^{\mathrm{a}}$ Després et al. (2012), ${ }^{\mathrm{b}}$ Hoose et al. (2010), ${ }^{\mathrm{c}} \underline{\text { Heald and Spracklen (2009). }}$.

5 Table 1: Fungal spore emissions, burdens, lifetimes, and number and mass concentrations in near surface air.

\begin{tabular}{|c|c|c|c|}
\hline & Specific humidity & Temperature & Leaf Area Index \\
\hline Urban Observations & 0.41 & 0.26 & -0.07 \\
\hline Non-Urban Observations & 0.02 & 0.15 & 0.41 \\
\hline
\end{tabular}

Table 2: Correlation between observations and the modeled specific humidity, temperature, and leaf area index. The values in bold are statistically significant $(\mathrm{p}<0.05)$. 
Atmos. Chem. Phys. Discuss., https://doi.org/10.5194/acp-2019-251

Manuscript under review for journal Atmos. Chem. Phys.

Discussion started: 17 April 2019

(c) Author(s) 2019. CC BY 4.0 License.
Atmospheric

Chemistry

and Physics

Discussions

\begin{tabular}{|c|c|c|c|c|c|c|c|c|c|c|c|}
\hline Location & $\mathrm{LON}$ & LAT & ALT & Instrument & Start & End & Season & Site category & Publication & \begin{tabular}{|c} 
Size \\
Range \\
$(\mu \mathrm{m})$
\end{tabular} & $\begin{array}{c}\text { Mean } \\
\left(10^{6} \mathrm{~m}^{-3}\right)\end{array}$ \\
\hline $\begin{array}{c}\text { Amazon, } \\
\text { Brazil }\end{array}$ & -60.2 & -2.58 & 110 & UV-APS & 03.02 .2008 & 15.03 .2008 & Winter & rainforest & $\frac{\text { Huffman et al., }}{2012)}$ & $>1$ & 0.093 \\
\hline $\begin{array}{c}\text { Karlsruhe, } \\
\text { Germany }\end{array}$ & 8.42 & 49.09 & 117 & WIBS-4A & 01.04 .2010 & 01.04 .2011 & Yearly & semi-rural & $\begin{array}{l}\text { (Toprak and } \\
\text { schnaiter, 2013) }\end{array}$ & $0.8-16$ & 0.031 \\
\hline $\begin{array}{c}\text { Karlsruhe, } \\
\text { Germany }\end{array}$ & 8.42 & 49.09 & 117 & WIBS-4A & 01.04 .2010 & 01.07 .2010 & Spring & semi-rural & $\begin{array}{l}\text { (Toprak and } \\
\text { schnaiter, 2013) }\end{array}$ & $0.8-16$ & 0.029 \\
\hline $\begin{array}{l}\text { Karlsruhe, } \\
\text { Germany }\end{array}$ & 8.42 & 49.09 & 117 & WIBS-4A & 01.07 .2010 & 01.10 .2010 & Summer & semi-rural & $\begin{array}{l}\text { (Toprak and } \\
\text { schnaiter, 2013) }\end{array}$ & $0.8-16$ & 0.046 \\
\hline $\begin{array}{c}\text { Karlsruhe, } \\
\text { Germany }\end{array}$ & 8.42 & 49.09 & 117 & WIBS-4A & 01.10 .2010 & 01.01 .2011 & Autumn & semi-rural & $\begin{array}{l}\text { (Toprak and } \\
\text { schnaiter, 2013) }\end{array}$ & $0.8-16$ & 0.029 \\
\hline $\begin{array}{c}\text { Karlsruhe, } \\
\text { Germany }\end{array}$ & 8.42 & 49.09 & 117 & WIBS-4A & 01.01 .2011 & 01.04 .2011 & Winter & semi-rural & $\begin{array}{l}\text { (Toprak and } \\
\text { schnaiter, 2013) }\end{array}$ & $0.8-16$ & 0.019 \\
\hline $\begin{array}{c}\text { Colorado, } \\
\text { USA }\end{array}$ & -105.15 & 39.16 & 2290 & UV-APS & 20.07 .2011 & 22.08 .2012 & Yearly & rural & $\frac{(\text { Schumacher et }}{\text { al., 2013) }}$ & $>1$ & \\
\hline $\begin{array}{c}\text { Colorado, } \\
\text { USA }\end{array}$ & -105.15 & 39.16 & 2290 & UV-APS & 01.03 & 31.05 & Spring & rural & $\frac{(\text { Schumacher et }}{\text { al., 2013) }}$ & $>1$ & 0.015 \\
\hline $\begin{array}{c}\text { Colorado, } \\
\text { USA }\end{array}$ & -105.15 & 39.16 & 2290 & UV-APS & 01.06 & 31.08 & Summer & rural & $\frac{(\text { Schumacher et }}{\text { al., 2013) }}$ & $>1$ & 0.03 \\
\hline $\begin{array}{c}\text { Colorado, } \\
\text { USA }\end{array}$ & -105.15 & 39.16 & 2290 & UV-APS & 01.09 & 30.11 & Autumn & rural & $\frac{(\text { Schumacher et }}{\text { al., 2013) }}$ & $>1$ & 0.017 \\
\hline $\begin{array}{c}\text { Colorado, } \\
\text { USA }\end{array}$ & -105.15 & 39.16 & 2290 & UV-APS & 01.12 & 29.02 & Winter & rural & $\frac{\text { (Schumacher et }}{\text { al., 2013) }}$ & $>1$ & 0.0053 \\
\hline $\begin{array}{c}\text { Hyytiälä, } \\
\text { Finland }\end{array}$ & 24.17 & 61.85 & 181 & UV-APS & 27.08 .2009 & 17.04 .2011 & Yearly & boreal forest & $\frac{(\text { Schumacher et }}{\text { al., 2013)) }}$ & $>1$ & \\
\hline $\begin{array}{c}\text { Hyytiälä, } \\
\text { Finland }\end{array}$ & 24.17 & 61.85 & 181 & UV-APS & 01.03 & 31.05 & Spring & boreal forest & $\frac{\text { (Schumacher et }}{\text { al., 2013) }}$ & $>1$ & 0.015 \\
\hline $\begin{array}{c}\text { Hyytiälä, } \\
\text { Finland }\end{array}$ & 24.17 & 61.85 & 181 & UV-APS & 01.06 & 31.08 & Summer & boreal forest & $\frac{(\text { Schumacher et }}{\text { al., 2013) }}$ & $>1$ & 0.046 \\
\hline $\begin{array}{c}\text { Hyytiälä, } \\
\text { Finland }\end{array}$ & 24.17 & 61.85 & 181 & UV-APS & 01.09 & 30.11 & Autumn & boreal forest & $\frac{(\text { Schumacher et }}{\text { al., 2013) }}$ & $>1$ & 0.027 \\
\hline $\begin{array}{c}\text { Hyytiälä, } \\
\text { Finland } \\
\end{array}$ & 24.17 & 61.85 & 181 & UV-APS & 01.12 & 29.02 & Winter & boreal forest & $\frac{(\text { Schumacher et }}{\text { al., 2013) }}$ & $>1$ & 0.004 \\
\hline $\begin{array}{l}\text { Killaney, } \\
\text { Ireland }\end{array}$ & -9.5 & 52.05 & 34 & WIBS-4A & 02.08 .2010 & 02.09 .2010 & Summer & rural & $\frac{\text { (Healy et al., }}{2014)}$ & $>1$ & 0.035 \\
\hline $\begin{array}{l}\text { Killaney, } \\
\text { Ireland }\end{array}$ & -9.5 & 52.05 & 34 & UV-APS & 02.08 .2010 & 02.09 .2010 & Summer & rural & $\frac{\text { (Healy et al., }}{2014)}$ & $>1$ & 0.015 \\
\hline $\begin{array}{c}\text { Mainz, } \\
\text { Germany }\end{array}$ & 8.23 & 49.98 & 100 & UV-APS & 03.08 .2006 & 04.12 .2006 & Autumn & semi-urban & $\frac{\text { Huffman et al., }}{2010)}$ & $>1$ & 0.027 \\
\hline $\begin{array}{l}\text { Borneo, } \\
\text { Indonesia }\end{array}$ & 117.84 & 4.98 & & WIBS-3 & 01.06 .2008 & 31.07 .2008 & Summer & forest & $\frac{\text { (Gabey et al., }}{2010)}$ & $0.8-20$ & 0.2 \\
\hline $\begin{array}{c}\text { Nanjing, } \\
\text { China }\end{array}$ & 118.95 & 32.12 & & WIBS-4A & 29.10 .2013 & 15.11 .2013 & Autumn & urban & Yu et al., 2013) & $>1$ & 2.09 \\
\hline \begin{tabular}{|c|} 
Puy de dôme, \\
France
\end{tabular} & 2.96 & 45.43 & 1465 & WIBS-3 & 22.06 .2010 & 03.07 .2010 & Summer & mountain & $\frac{\text { (Gabey et al., }}{2013)}$ & $>1$ & 0.095 \\
\hline \begin{tabular}{|c|} 
Manchester, \\
UK \\
\end{tabular} & -2.25 & 53.48 & & WIBS-3 & 04.12 .2009 & 21.12 .2009 & Winter & urban & $\frac{\text { (Gabey et al., }}{2011)}$ & $0.8-20$ & 0.11 \\
\hline $\begin{array}{c}\text { Helsinki, } \\
\text { Finland }\end{array}$ & 24.65 & 60.2 & & UV-APS & 02.02 .2012 & 25.02 .2012 & Winter & suburban & $\frac{\text { (Saari et al., }}{2015)}$ & $<1$ & NA \\
\hline $\begin{array}{c}\text { Helsinki, } \\
\text { Finland }\end{array}$ & 24.65 & 60.2 & & UV-APS & 16.06 .2012 & 22.08 .2012 & Summer & urban & $\frac{\text { (Saari et al., }}{2015)}$ & $>1$ & 0.013 \\
\hline $\begin{array}{c}\text { Helsinki, } \\
\text { Finland }\end{array}$ & 24.65 & 60.2 & & BIO-SCOUT & 02.02 .2012 & 25.02 .2012 & Winter & suburban & $\frac{\text { (Saari et al., }}{2015)}$ & $>1$ & 0.01 \\
\hline $\begin{array}{c}\text { Helsinki, } \\
\text { Finland }\end{array}$ & 24.65 & 60.2 & & BIO-SCOUT & 16.06 .2012 & 22.08 .2012 & Summer & urban & $\frac{\text { (Saari et al., }}{2015)}$ & $>1$ & 0.028 \\
\hline Munnar, India & 77.06 & 10.09 & 1605 & UV-APS & 01.06.2014 & 20.08 .2014 & Summer & rural & (Valsan et al., & $>1$ & 0.017 \\
\hline
\end{tabular}


Atmos. Chem. Phys. Discuss., https://doi.org/10.5194/acp-2019-251

Manuscript under review for journal Atmos. Chem. Phys.

Discussion started: 17 April 2019

(c) Author(s) 2019. CC BY 4.0 License.

(c) (i)

\begin{tabular}{|c|c|c|c|c|c|c|c|c|c|c|c|}
\hline & & & & & & & & & 2016) & & \\
\hline $\begin{array}{c}\text { Ucluelet, } \\
\text { Canada }\end{array}$ & -125.54 & 48.92 & 5 & WIBS-4A & 06.08 .2013 & 28.08 .2013 & Summer & rural/marine & unpublished & $>1$ & 0.059 \\
\hline Paris, France & 2.35 & 48.85 & & UV-APS & 14.01 .2010 & 15.02 .2010 & Winter & urban & unpublished & $>0.8$ & 0.0276 \\
\hline $\begin{array}{l}\text { Saclay, } \\
\text { France }\end{array}$ & 2.17 & 48.71 & & UV-APS & 16.06 .2014 & 05.08 .2014 & Summer & semi-urban & unpublished & $>0.8$ & 0.027 \\
\hline $\begin{array}{l}\text { Saclay, } \\
\text { France }\end{array}$ & 2.17 & 48.71 & & WIBS-4A & 16.06 .2014 & 05.08 .2014 & Summer & semi-urban & unpublished & $>0.8$ & 0.088 \\
\hline Cyprus & 33.06 & 35.03 & 550 & WIBS-4A & 01.04 .2016 & 26.04 .2016 & Spring & $\begin{array}{c}\text { rural } / \text { mountai } \\
n\end{array}$ & unpublished & $>0.8$ & 0.0433 \\
\hline Barbados & -59.43 & 13.16 & 5 & WIBS-4A & 16.07 .2016 & 04.09 .2016 & Summer & rural/marine & unpublished & $>0.8$ & 0.0951 \\
\hline
\end{tabular}

Table 3: List of the FBAP observations. 
Atmos. Chem. Phys. Discuss., https://doi.org/10.5194/acp-2019-251

Manuscript under review for journal Atmos. Chem. Phys.

Discussion started: 17 April 2019

(c) Author(s) 2019. CC BY 4.0 License.

(c) (i)

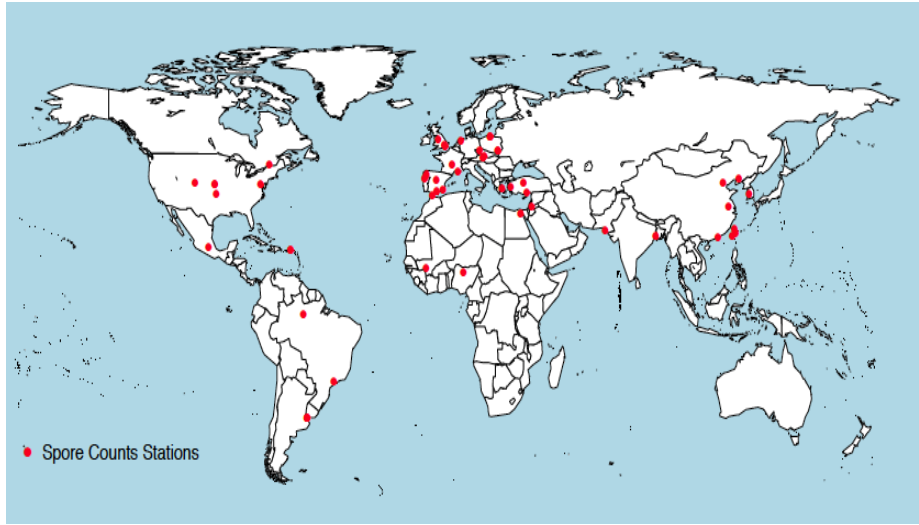

Figure 1: Geographical locations of the fungal spore counts listed in Table SI2 and used in Fig. 4 
Atmos. Chem. Phys. Discuss., https://doi.org/10.5194/acp-2019-251

Manuscript under review for journal Atmos. Chem. Phys.

Discussion started: 17 April 2019

(c) Author(s) 2019. CC BY 4.0 License.
Atmospheric

Chemistry

and Physics

Discussions

(c) (1)
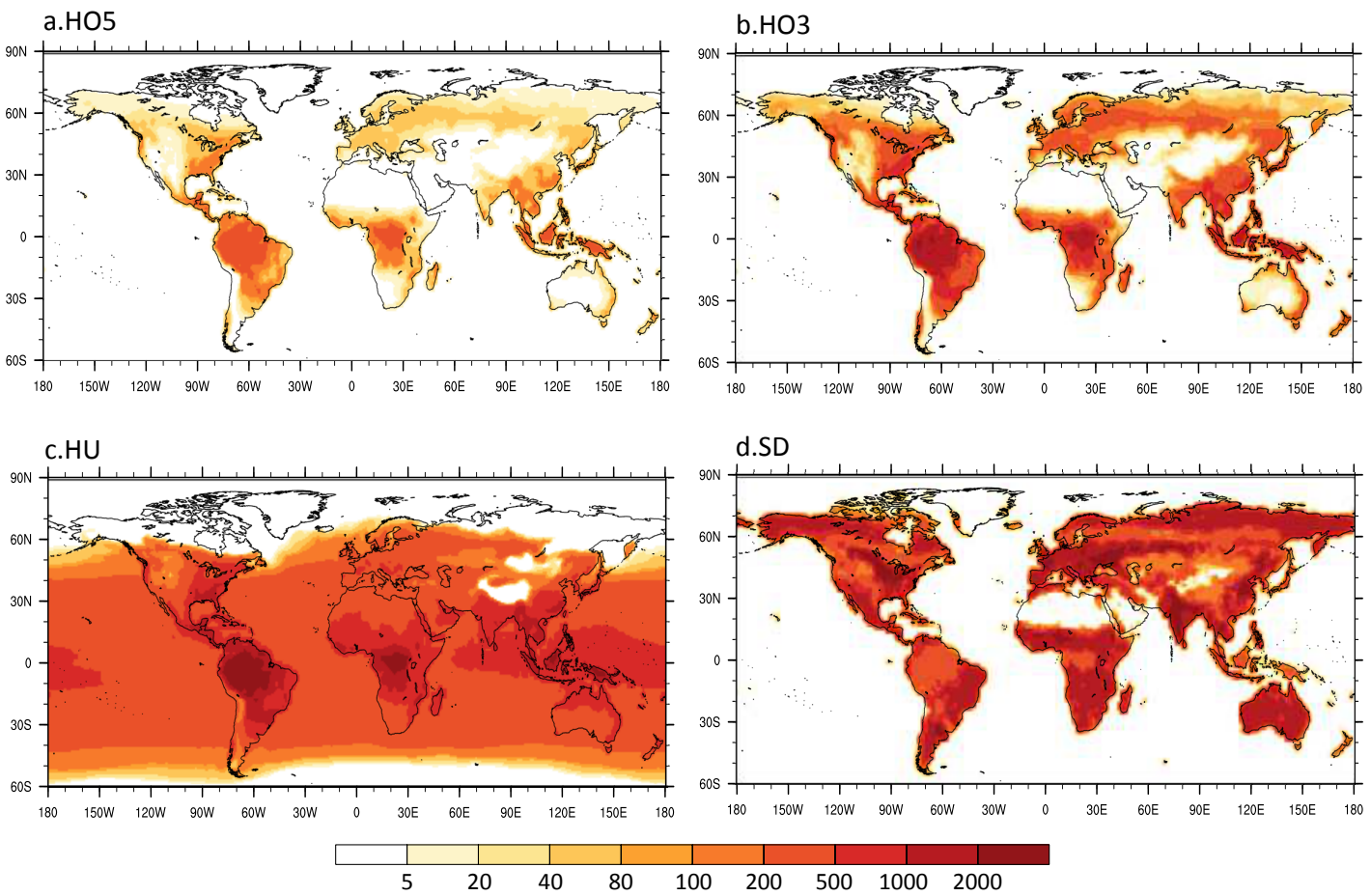

Figure 2: Modeled annual mean emission fluxes of fungal spores (in $\mathrm{m}^{-2} \mathrm{~s}^{-1}$ ). 
Atmos. Chem. Phys. Discuss., https://doi.org/10.5194/acp-2019-251

Manuscript under review for journal Atmos. Chem. Phys.

Discussion started: 17 April 2019

(c) Author(s) 2019. CC BY 4.0 License.
Atmospheric

Chemistry

and Physics

Discussions
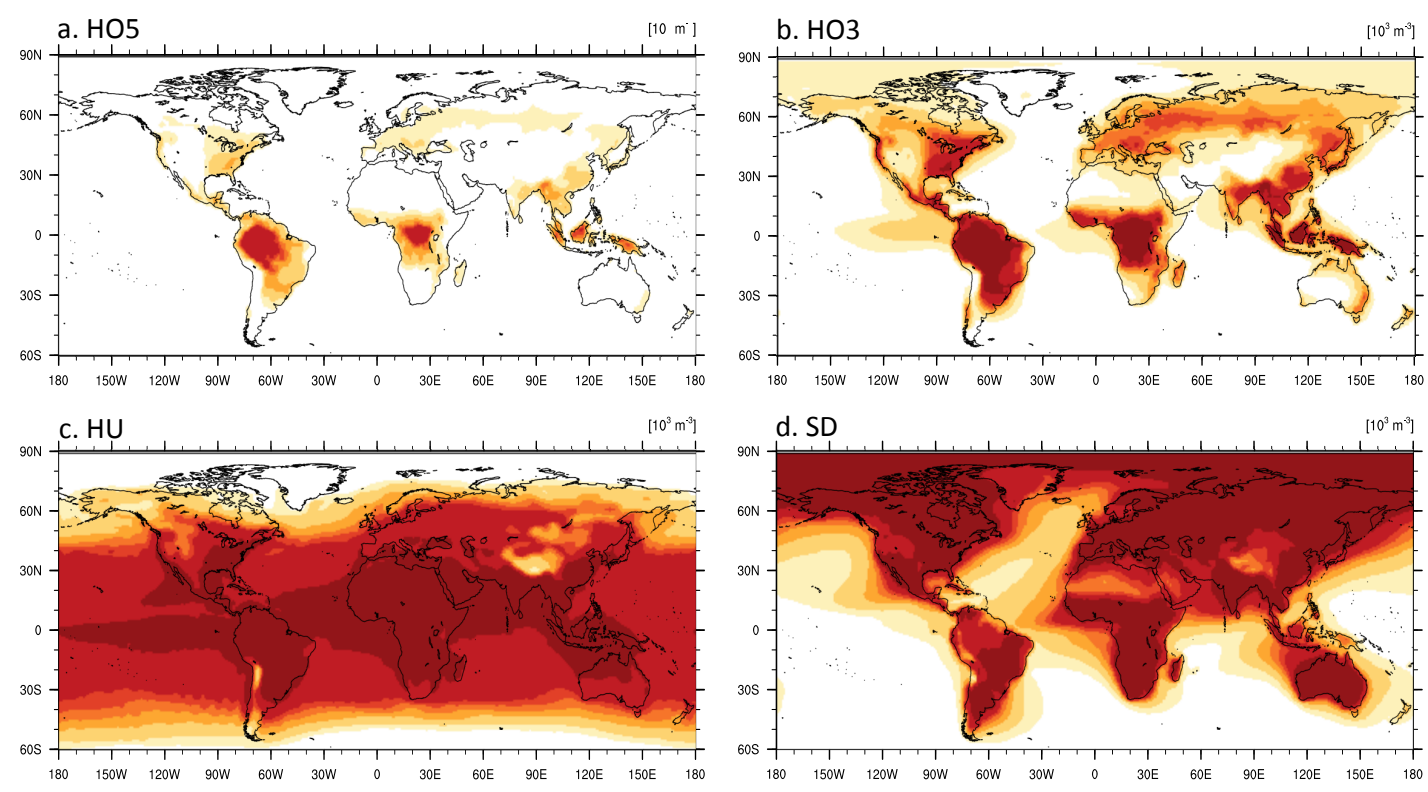

d. SD
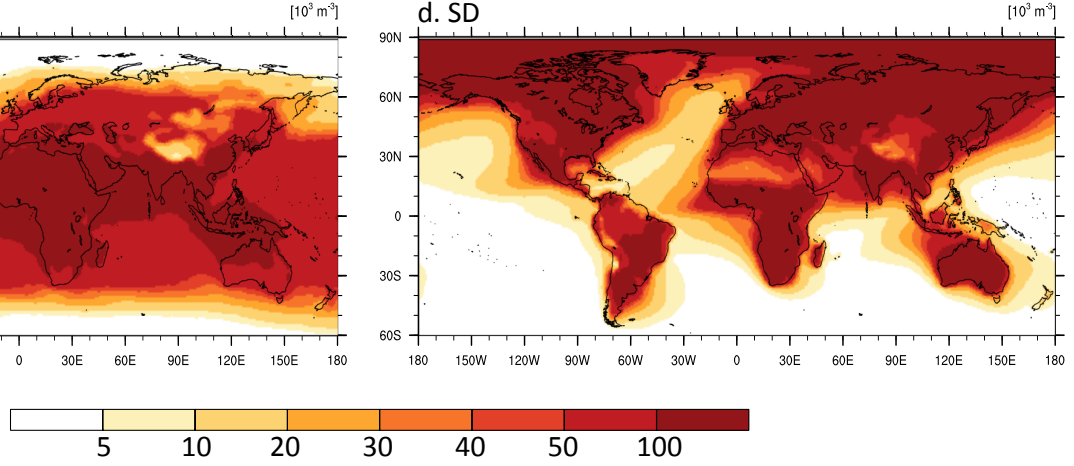

Figure 3: Modeled near-surface annual mean number concentration of fungal spores (in $10^{3} \mathrm{~m}^{-3}$ ). 
Atmos. Chem. Phys. Discuss., https://doi.org/10.5194/acp-2019-251

Manuscript under review for journal Atmos. Chem. Phys.

Discussion started: 17 April 2019

(c) Author(s) 2019. CC BY 4.0 License.
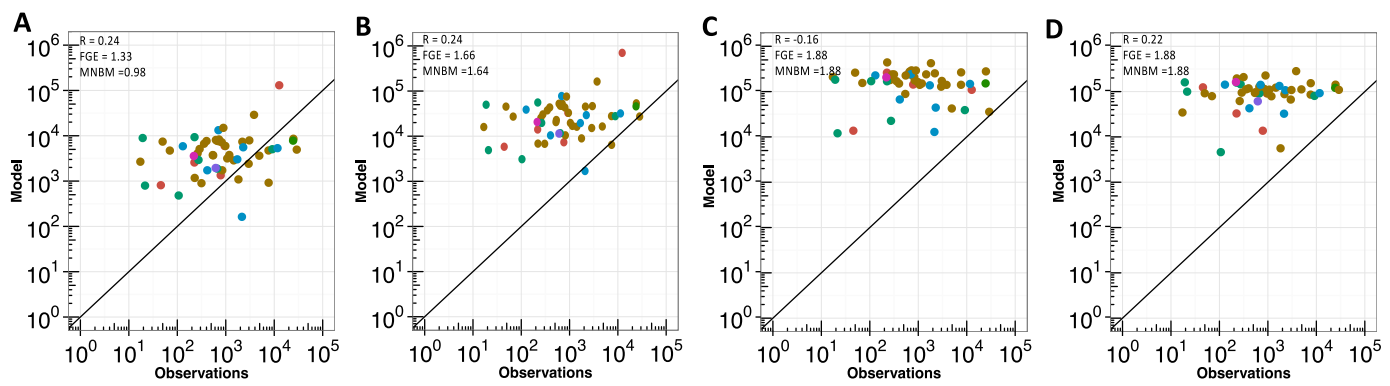

Figure 4: Comparisons between fungal spore number concentrations $\left(\right.$ in $^{-3}$ ) observed and simulated by EMAC using the three emission parameterizations (including the two versions of (Hoose et al., 2010) HO5 and HO3). A. HO5, B. HO3, C. HU and D. SD. Colored points depict the ecosystems of the observational stations as defined by MODIS. 
Atmos. Chem. Phys. Discuss., https://doi.org/10.5194/acp-2019-251

Manuscript under review for journal Atmos. Chem. Phys.

Discussion started: 17 April 2019

(c) Author(s) 2019. CC BY 4.0 License.
Atmospheric

Chemistry

and Physics

Discussions

(c) (i)
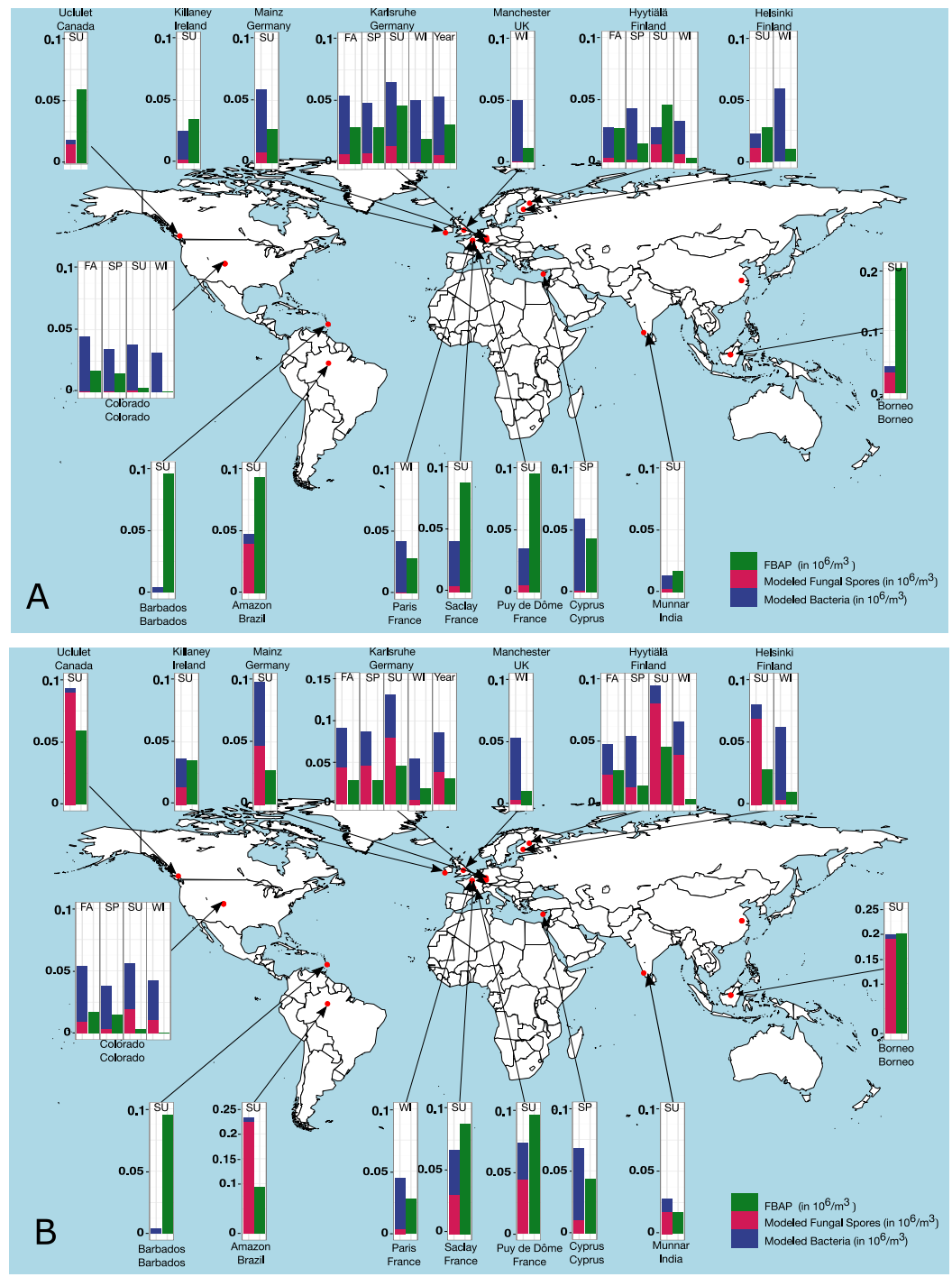

Figure 5: Comparisons between observed FBAP and modeled bacteria and fungal spores sampled for the campaigns described in Table 3. Units: $10^{6} \mathrm{~m}^{-3}$. Observations are seasonal, Fall (FA), Spring (SP), and Winter (WI), and yearly (Year) 
Atmos. Chem. Phys. Discuss., https://doi.org/10.5194/acp-2019-251

Manuscript under review for journal Atmos. Chem. Phys.

Discussion started: 17 April 2019

(c) Author(s) 2019. CC BY 4.0 License.

(c) (1)

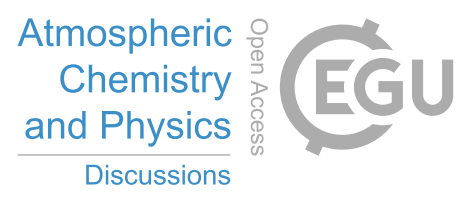

A. Fungal spores are calculated using HO5. Data from Borneo are plotted on a different scale because of the high particle count observations and data from Nanjing, China were removed due to large urban influence. B. Fungal spores are

calculated using HO3. Data from the Amazon, Borneo, and Karlsruhe are plotted on a different scale because of the high particle count observations and data from Nanjing, China were removed due to large urban influence. 